\title{
Mental Health Promotion and Early Intervention in Early Childhood and Primary School Settings: A Review ${ }^{1}$
}

\author{
Frances Kay-Lambkin \\ National Drug and Alcohol Research Centre, University of New \\ South Wales, and Hunter Institute of Mental Health
}

\section{Elizabeth Kemp}

Hunter Institute of Mental Health

\author{
Karen Stafford \\ Hunter Institute of Mental Health
}

\section{Trevor Hazell}

Hunter Institute of Mental Health

\begin{abstract}
Response Ability is an initiative of the Australian Government Department of Health and Ageing (the Department). Since 2000, the project team has provided free multimedia resources and practical support for universities and teacher educators, addressing pre-service education for secondary teachers. The focus of the existing Response Ability resources is on the mental health and wellbeing of secondary school students. The use of these resources is designed to encourage pre-service teachers to engage with and promote social and emotional health in their teaching practices. In 2006, the Response Ability project was directed by the Department to advise how the scope of these resources could be broadened to support primary and early childhood teacher education. As part of this, a large-scale scoping study was undertaken to inform discussions about mental health promotion and early intervention
\end{abstract}

The review described in this paper was supported by funding from the Australian Government

Department of Health and Ageing, as part of the national Response Ability teacher education initiative. 
strategies in primary and early childhood settings. A structured literature review was completed as part of this process, examining three key questions:

- What are the mental health issues facing children in early childhood and the primary school years?

- What role can educators have in addressing these issues?

- What training do educators need in order to fulfil this role?

The following article discusses the findings of this literature review.

\section{Introduction}

Response Ability is an initiative of the Australian Government Department of Health and Ageing. The existing teacher education component of the project supports the pre-service preparation of secondary teachers to assist with managing the social and emotional wellbeing (or mental health) of adolescents.

The project team provides free multimedia resources and practical support for universities and teacher educators, and disseminates information and research on these issues. Case studies explore the roles of teachers in promoting resilience and wellbeing and in responding to young people with social or emotional problems. All resources are based on extensive consultation and developed collaboratively by health professionals and teacher educators.

Across Australia, over $90 \%$ of university campuses are using the Response Ability resources for secondary education, with $75 \%$ of these using them in core units within the pre-service education curriculum. The existing resources concentrate on secondary and middle schooling. However, the funding body is currently considering the development of a multimedia resource package for use with primary and early childhood pre-service teachers.

In 2006, the Response Ability teacher education project team completed a multi-component scoping study designed to inform planning and discussion about mental health promotion and early intervention strategies in primary and early childhood educational settings.

The scoping study was intended to complement the existing work by MindMatters (www.curriculum.edu.au/mindmatters) and Response Ability (www.responseability.org), as well as the KidsMatter (www.kidsmatter.edu.au) initiative, which is being trialled in primary school settings.

The scoping study consisted of three components:

- a literature review on mental health promotion and early intervention in early childhood and primary settings;

- a study of staffing profiles and staff training in early childhood settings in Australia; and 
- $\quad$ consultation with teacher educators from a minimum of $80 \%$ of Australian campuses that offer primary or early childhood teacher education programs.

In this document, we report the findings of the literature review, which examined three questions:

- What are the mental health issues facing children in early childhood and the primary school years?

- What role can educators have in addressing these issues?

- What training do educators need in order to fulfil this role?

\section{Methodology}

The literature was systematically searched to find publications covering the mental health, wellbeing and resilience of children. Table 1 summarises the key search strategies and keywords and the number of documents found.

Table 1 - Search Strategies

\begin{tabular}{|c|c|c|c|}
\hline $\begin{array}{l}\text { Research } \\
\text { Question }\end{array}$ & Key search terms & Search Strategy & Results \\
\hline $\begin{array}{l}\text { What are } \\
\text { the mental } \\
\text { health } \\
\text { issues } \\
\text { facing } \\
\text { children? }\end{array}$ & $\begin{array}{l}\text { disorders, risk factors, early } \\
\text { indicators, resilience, } \\
\text { wellbeing, mental health, } \\
\text { developmental factors, } \\
\text { depression, anxiety and } \\
\text { attachment, infancy, } \\
\text { children, childhood }\end{array}$ & $\begin{array}{l}\text { Electronic databases: } \\
\text { MEDLINE (1966-2006) } \\
\text { PsycINFO (1984-2006) } \\
\text { World Wide Web: } \\
\text { Google and Google } \\
\text { Scholar } \\
\text { auseinet.flinders.edu.au }\end{array}$ & $\begin{array}{l}74 \\
\text { potentially } \\
\text { relevant } \\
\\
\\
18 \\
\text { highly } \\
\text { relevant }\end{array}$ \\
\hline $\begin{array}{l}\text { How can } \\
\text { educators } \\
\text { promote } \\
\text { mental } \\
\text { health and } \\
\text { wellbeing } \\
\text { among } \\
\text { children? }\end{array}$ & $\begin{array}{l}\text { As above and: } \\
\text { mental health promotion, } \\
\text { teacher, educator, mental } \\
\text { health, resilience, resiliency, } \\
\text { wellbeing, strategies, } \\
\text { programs, training, teacher } \\
\text { mental health } \\
\text { Also examined parenting } \\
\text { programs for principles that } \\
\text { might be transferable to } \\
\text { educational practice. }\end{array}$ & $\begin{array}{l}\text { Electronic databases: } \\
\text { Australian Education } \\
\text { Index (AEI); Education } \\
\text { Resources Information } \\
\text { Centre (ERIC) } \\
\text { PsycINFO } \\
\text { World Wide Web: } \\
\text { Google and Google } \\
\text { Scholar }\end{array}$ & $\begin{array}{c} \\
\\
22 \\
\text { highly } \\
\text { relevant } \\
\text { documents }\end{array}$ \\
\hline
\end{tabular}




\begin{tabular}{|c|c|c|c|}
\hline & $\begin{array}{l}\text { Also searched by key } \\
\text { authors known to publish in } \\
\text { relevant areas. }\end{array}$ & $\begin{array}{l}\text { auseinet.flinders.edu.au } \\
\text { www.aare.edu.au } \\
\text { www.acer.edu.au } \\
\text { www.casel.org }\end{array}$ & \\
\hline $\begin{array}{l}\text { How can } \\
\text { educators } \\
\text { be trained } \\
\text { to } \\
\text { promote } \\
\text { mental } \\
\text { health and } \\
\text { wellbeing } \\
\text { among } \\
\text { children? }\end{array}$ & $\begin{array}{l}\text { combinations of: } \\
\text { mental health, training, } \\
\text { teacher, educator, teacher } \\
\text { training, teacher education, } \\
\text { children, infant, classroom, } \\
\text { wellbeing, resilience or } \\
\text { resiliency, wellbeing, } \\
\text { training program, parents or } \\
\text { parenting. } \\
\text { Also examined teacher } \\
\text { stress, burnout, } \\
\text { performance, ability to help } \\
\text { students, teaching style, } \\
\text { teachers leaving profession, } \\
\text { teacher retention etc. } \\
\text { Also examined pre-service } \\
\text { and post-graduate university } \\
\text { offerings. }\end{array}$ & $\begin{array}{l}\text { Electronic databases: } \\
\text { ERIC; MEDLINE; } \\
\text { PsycINFO } \\
\text { World Wide Web: } \\
\text { Google and Google } \\
\text { Scholar } \\
\text { auseinet.flinders.edu.au } \\
\text { www.aare.edu.au } \\
\text { www.acer.edu.au } \\
\text { www.casel.org } \\
\text { Australian university } \\
\text { websites }\end{array}$ & $\begin{array}{c}29 \\
\text { highly } \\
\text { relevant }\end{array}$ \\
\hline $\begin{array}{l}\text { Additional } \\
\text { searches }\end{array}$ & \multicolumn{2}{|c|}{$\begin{array}{l}\text { The search was augmented by personal communication } \\
\text { with people working in relevant areas, and attendance at } \\
\text { health and educational conferences. Some unpublished } \\
\text { papers were noted. }\end{array}$} & $\begin{array}{c}25 \\
\text { documents }\end{array}$ \\
\hline
\end{tabular}

\section{What are the mental health issues facing children?}

Children and adolescents make up $26 \%$ of the population in Australia. It is widely accepted that the early years, exerts considerable influence on their development, and their mental health and resilience throughout their life (Aguirregabiria, 2006).

Modern-day families face many economic and social pressures, including unemployment, family breakdown, and welfare system issues, increasing the exposure of children to stress and hardship, and in some cases family violence (Greenberg et al., 2003; Holmes, Slaughter, \& Kashani, 2001; Wolff, 1995). These experiences, along with internal and external factors, will influence the extent to which children achieve developmental milestones, and develop into well-adjusted, resilient young people and adults (Wolff, 1995). At the same time, early childhood is associated with a number of formal mental disorders that, if left unrecognised, can 
further add to the difficulties experienced by adolescents and adults, and can lead to additional comorbid mental health problems.

\section{Mental disorders among children}

The period of early childhood is the first five years of life, with preschool children typically being those aged between 2 and 5 yrs (Egger \& Angold, 2006). This is a time of rapid change and development and the diagnosis of psychiatric disorders among this group can be problematic, with the potential for normal adjustment behaviours to be labelled as disordered (Bernstein, Borchardt, \& Perwien, 1996). Despite this, experts have typically clustered mental disorders among this group of children into two main groups: externalising disorders (e.g., attention deficit hyperactivity disorder, oppositional defiant disorder, and conduct disorder) and internalising disorders (e.g., anxious and depressive disorders) (APA, 2000; Egger \& Angold, 2006).

Globally, anxiety disorders have been reported in approximately $9 \%$ of children, emotional (depressive) conditions in about $11-15 \%$ of children, and behavioural (externalising) disorders in approximately $9-15 \%$ of children (Bernstein, Borchardt, \& Perwien, 1996). The Australian National Survey of Mental Health and Wellbeing (Sawyer et al., 2001) estimated that among children aged 4-16 years, rates of mental disorder were approximately 14\%. Attention Deficit Hyperactivity Disorder was the most common condition reported by this age group (ADHD, 11\%), followed by depression (4\%) and conduct disorder (3\%) (Sawyer et al., 2001). One in ten preschool children (aged 3-5) in a survey conducted in South Australia in 2005, reported significant mental health problems, including emotional, behavioural and social skills deficits (see DECS, 2006).

While the incidence of some conditions such as ADHD decreases with increasing age, other conditions such as depression tend to increase with age. Holmes and colleagues (2001) suggest that it is important for parents, educators and health professionals to have a clear understanding of the risk factors for the most common mental disorders in early childhood and later life, thereby facilitating early identification and early intervention of problem behaviours before they escalate (Holmes, Slaughter, \& Kashani, 2001).

\section{Risk factors for mental disorders as manifested in early childhood and primary school years}

Risk factors are those internal characteristics and external conditions that affect young children, increasing the likelihood of mental disorders either during the early years of life, or in adolescence and adulthood (OMH, 2002). While a single risk factor on its own may not have a significant effect on a young child, several risk factors interacting with each other will strongly influence development (DoHA, 2000). These factors can serve as a marker for early intervention.

Table 2 summarises the key risk factors relevant to young children that are associated with negative mental health and wellbeing, according to available evidence and expert opinion. It is important to note, however, that the relationship 
between these risk factors and negative outcomes is not directly cause and effect. Rather, different combinations of risk factors will influence different children in different ways (DoHA, 2000).

In general, the early risk factors for the development of anxiety and depression in later life are most often manifested through behavioural inhibition among preschool and primary-aged children (Bernstein, Borchardt, \& Perwien, 1996). Key indicators displayed by young children at risk of these conditions include extreme shyness, timidity, fear, withdrawal and avoidance of new situations, anxious or fearful distress, and signs of emotional restraint around unfamiliar people, places and activities (Beitchman, Inglis, \& Schachter, 1992a; Bernstein, Borchardt, \& Perwien, 1996; Donovan \& Spence, 2000). Correlates of depressive and anxious disorders in childhood also include the experience of adverse life events, and an absence of peers in whom to confide (Burns, Andrews, \& Szabo, 2002; Lagges \& Dunn, 2003; Wolff, 1995). Parents who tend to model, prompt and reinforce anxious behaviours in their children, who exhibit signs of over-control, over-protection, and anxious behaviours in themselves, also place their children at high risk of developing an internalising disorder (Beitchman, Inglis, \& Schachter, 1992a; Bernstein, Borchardt, \& Perwien, 1996; Donovan \& Spence, 2000). Teachers and parents can misinterpret or even miss anxious or depressive behaviours in children, given that these symptoms often lead to a child being compliant and nondisruptive (Holmes, Slaughter, \& Kashani, 2001). These risk factors will have a cumulative effect on the young child, and are magnified in the context of early childhood adversity, parental depression and non-supportive school and family environments (Beitchman, Inglis, \& Schachter, 1992a; Burns, Andrews, \& Szabo, 2002).

Table 2 - Risk factors relevant to young children and associated with negative mental health outcomes*

\begin{tabular}{|c|c|c|c|}
\hline $\begin{array}{l}\text { Individual (Child) } \\
\text { Indicators }\end{array}$ & Family Context & Social Context & $\begin{array}{l}\text { School } \\
\text { Context }\end{array}$ \\
\hline $\begin{array}{l}\text { behavioural } \\
\text { inhibition } \\
\text { extreme shyness } \\
\text { fearfulness } \\
\text { withdrawal } \\
\text { avoidance of new } \\
\text { situations } \\
\text { anxious/fearful } \\
\text { distress } \\
\text { excessive compliance }\end{array}$ & $\begin{array}{l}\text { parenting style } \\
\text { over control } \\
\text { reinforcing anxious } \\
\text { behaviours } \\
\text { inconsistent } \\
\text { supervision } \\
\text { harsh punishment } \\
\text { rejection } \\
\text { lack of warmth and } \\
\text { affection }\end{array}$ & $\begin{array}{l}\text { relationships } \\
\text { with peers } \\
\text { bullying } \\
\text { social exclusion } \\
\text { peer rejection } \\
\text { social withdrawal } \\
\text { difficulties } \\
\text { engaging in play } \\
\text { socioeconomic } \\
\text { disadvantage }\end{array}$ & $\begin{array}{l}\text { environment } \\
\text { inadequate } \\
\text { behavioural } \\
\text { management or } \\
\text { supervision } \\
\text { unsafe } \\
\text { school } \\
\text { performance } \\
\text { failure }\end{array}$ \\
\hline
\end{tabular}




\begin{tabular}{|c|c|c|c|}
\hline $\begin{array}{l}\text { behaviour } \\
\text { disinhibition } \\
\text { low harm avoidance } \\
\text { irritability } \\
\text { high novelty seeking } \\
\text { argumentativeness } \\
\text { excessive non- } \\
\text { compliance } \\
\text { aggression } \\
\text { difficulty anticipating } \\
\text { consequences of } \\
\text { behaviour } \\
\text { general } \\
\text { low intelligence } \\
\text { poor language skills } \\
\text { poor attachments } \\
\text { failure to achieve } \\
\text { normal } \\
\text { developmental } \\
\text { milestones }\end{array}$ & $\begin{array}{l}\text { lack of involvement } \\
\text { in child's activities } \\
\text { parental illness } \\
\text { mental } \\
\text { physical } \\
\text { substance use } \\
\text { family functioning } \\
\text { divorce/separation } \\
\text { single parenting } \\
\text { large family } \\
\text { family violence or } \\
\text { disharmony } \\
\text { unemployment } \\
\text { criminality }\end{array}$ & $\begin{array}{l}\text { social or } \\
\text { cultural } \\
\text { discrimination }\end{array}$ & $\begin{array}{l}\text { poor } \\
\text { attachment to } \\
\text { school } \\
\text { inconsistent } \\
\text { attendance } \\
\text { difficult } \\
\text { school } \\
\text { transition }\end{array}$ \\
\hline
\end{tabular}

* Based on evidence and expert opinion as outlined in the accompanying text. Note that the presence of risk factors does not imply a negative outcome.

In contrast, the risk factors for disruptive behavioural (or externalising) disorders, are associated with behavioural disinhibition (Bernstein, Borchardt, \& Perwien, 1996). Signs include high novelty seeking, low harm avoidance, and irritable distress (Beitchman, Inglis, \& Schachter, 1992b; Bernstein, Borchardt, \& Perwien, 1996), along with argumentativeness, non-compliance, and difficulty analysing and anticipating consequences and learning from past behaviour (Holmes, Slaughter, \& Kashani, 2001). Socioeconomic disadvantage has also been associated with the development of these externalising disorders, although the exact nature of this relationship is still unclear (Beitchman, Inglis, \& Schachter, 1992a; Holmes, Slaughter, \& Kashani, 2001).

Along with these indicators, a parenting style that involves inconsistent supervision, harsh punishment, and rejection will further increase the risk of externalising disorders and difficulties in later life (Holmes, Slaughter, \& Kashani, 2001). Further, childhood aggression and poor peer relationships during preschool years is predictive of delinquency, substance use, and poor academic achievement in later childhood and adolescence. It often leads to aggressive children seeking out 
friendships with other rejected children who may reinforce these behaviours (Beitchman, Inglis, \& Schachter, 1992a).

In addition, problematic events in the early years of life have also been linked to the risk of developing depression, anxiety and substance use problems in later life. These events include difficult school transitions, parental divorce or separation, bullying at school and other forms of social exclusion, and changed family financial circumstances (McGrath, 2000). In a survey of 3-5 year old preschoolers in South Australia, the key correlates of psychiatric morbidity included poverty, family dysfunction, high life stress, parent mental illness, academic problems, and chronic physical illness (see DECS, 2006). These factors have also been associated with lower levels of resilience and poorer mental health outcomes in children in other countries (Doll \& Lyon, 1998). Educators involved with young children are in a good position to identify exposure to some risk factors such as harsh, punishmentdriven discipline, and high levels of family stress.

However, a large body of research is emerging that indicates that not all children who experience these risk factors in early life develop dysfunction or mental disorders in adulthood (e.g., Doll \& Lyon, 1998; Durlak \& Wells, 1997; Werner, 1995; Wolff, 1995). Importantly, it seems that the effects of these risk factors can be moderated by protective factors that serve as a buffer against risk factors and promote resiliency and positive adjustment within the child.

\section{Protective factors for mental disorders in children}

A resilient young person is typically one who has been exposed to significant risk or adversity and who demonstrates positive adjustment and good outcomes, particularly mental health outcomes, in response to these experiences (Luther, Cicchetti, \& Becker, 2000). The development of resiliency is a gradual process, rather than one that just happens later in life (Alvord \& Grados, 2005). While some forms of hardship cannot be eliminated, internal factors (such as positive coping skills) and external factors (supportive environments) can be fostered, particularly in the early years of development, to buffer against the effects of adverse life events and promote positive adjustment and outcome (Friedman \& Chase-Lansdale, 2002; Lynch, Geller, \& Schmidt, 2004). The early years of life are a time when mental health and social factors can be targeted to maximise resilience, and potentially reduce the risk of developing mental health problems and later difficulties (Farrell \& Travers, 2005). These protective factors are summarised in Table 3, and described in detail below. 
Table 3 - Protective factors in young children that are associated with increased resiliency and reduction of risk of mental disorders*

\begin{tabular}{|c|c|}
\hline Internal (child) factors & External (environment) factors \\
\hline $\begin{array}{l}\text { secure, supportive attachments } \\
\text { family } \\
\text { peers } \\
\text { other adults } \\
\text { sense of connectedness } \\
\text { outlook } \\
\text { positive expectations of self } \\
\text { hopefulness for the future } \\
\text { independence or autonomy } \\
\text { skill base } \\
\text { good communication skills } \\
\text { good problem-solving skills } \\
\text { intelligence } \\
\text { social skills } \\
\text { good self-regulation (behaviour, } \\
\text { emotions) }\end{array}$ & $\begin{array}{l}\text { positive climate (home and school) } \\
\text { warmth } \\
\text { safety } \\
\text { security } \\
\text { consistency (firm limits and } \\
\text { boundaries) } \\
\text { opportunity for participation in a } \\
\text { range of activities } \\
\text { school, community, home } \\
\text { at least one positive adult } \\
\text { relationship } \\
\text { school, community, home }\end{array}$ \\
\hline
\end{tabular}

* Based on evidence and expert opinion as outlined in the accompanying text. Note that the presence of protective factors does not assure a positive outcome.

The internal factors in early childhood most often associated with increased resilience and 'protection' from adversity, include good communication skills, effective problem solving skills, and the ability to regulate one's own behaviour, emotions and attention (e.g., ability to self-soothe or calm down, Beitchman, Inglis, \& Schachter, 1992a; Durlak \& Wells, 1997; Howard \& Johnson, 2000; Lynch, Geller, \& Schmidt, 2004). In addition, a young child's success at making friends and forming secure attachments with family and peer groups has been suggested to foster positive social, emotional and educational adjustment (Beitchman, Inglis, \& Schachter, 1992a). Holmes, Slaughter and Kashani (2001) further indicated that the ability of young children to make the most of their educational and other experiences will also protect them from stress and other risk factors. As such, the intelligence of the young child plays a role in enhancing resilience and acceptance. For example, young children with poor language skills and lower IQ will be more likely to experience peer rejection and negative teacher interactions; factors 
associated with future delinquency and conduct disorders (Alvord \& Grados, 2005; Doll \& Lyon, 1998; Holmes, Slaughter, \& Kashani, 2001).

A sense of independence, as well as hopefulness or high expectations for the future are also associated with increased resilience and protection from stress and adversity among young children (Benard, 1993; Howard \& Johnson, 2000; Lynch, Geller, \& Schmidt, 2004).

The external environment in which a young child develops can have either a deleterious or cushioning effect on their resilience, mental health and wellbeing. A warm, safe and secure environment can be protective for young children (Benard, 1993; Durlak \& Wells, 1997; Egger \& Angold, 2006; Farrell \& Travers, 2005). For example, Benard (1993) suggested that, in addition to internal factors, providing the young child with a safe, caring environment, with ongoing opportunities for participation in a variety of activities, is associated with the development of resilience.

The presence of at least one caring, competent adult, who is not part of the family and who defines firm limits and boundaries for the young child, has also been associated with resiliency (Doll \& Lyon, 1998; Howard \& Johnson, 2000; Lynch, Geller, \& Schmidt, 2004). For example, in a study of the role of teachers in the resilience of young people, Werner (1995) found that all the resilient high-risk children had at least one teacher who supported them. Among 3-5 year olds in a South Australian study group, supportive relationships with teachers were associated with higher self-esteem and greater mental health resilience (see DECS, 2006).

\section{How can educators promote mental health and wellbeing among children?}

Educators are ideally placed to promote mental health, wellbeing and resilience among children, as they have frequent contact with children at a time when their social, emotional, physical and mental development is most malleable (Doll \& Lyon, 1998; Schweinhart \& Weikart, 1998). Several authors have suggested that the education sector can serve as a quasi-mental health care system for children at risk of developing mental health problems, as well as for the entire child population (e.g., Burns et al., 1995). Indeed, educators are in an ideal position to monitor exposure to risk factors for mental disorder, and enhance protective factors for all children to maximise their resiliency and wellbeing (Alvord \& Grados, 2005; Benard, 1993; Koller \& Scvoboda, 2002).

The idea that an education-based approach to improving the social, emotional and academic development of children should be in place across the educational spectrum (i.e., preschool through to high school) is supported by a number of authors (e.g., Alvord \& Grados, 2005; Farrell \& Travers, 2005; Greenberg et al., 2003; Koller \& Scvoboda, 2002). In particular, programs based on the concept of proactively enhancing resilience in young children (reducing risk factors and enhancing protective factors) within school or pre-school are now being developed and tested in real world settings (Lynch, Geller, \& Schmidt, 2004). By fostering the 
development of children's personal skills and by influencing their environment, experts suggest that resilience factors are increased and the effect of the risk factors for mental disorder can be offset (DEST, 2003; McGrath, 2000; Myers-Walls, 2004).

Table 4 outlines the key approaches educators can take to enhance mental health and wellbeing among children. These approaches are described in detail in the following sections.

Table 4 - The ways in which educators can positively influence mental health and wellbeing and prevent mental disorders in young children

\begin{tabular}{|c|c|c|}
\hline $\begin{array}{l}\text { Universal approaches } \\
\text { for all young children, } \\
\text { regardless of risk* }\end{array}$ & $\begin{array}{l}\text { Selective approaches for } \\
\text { at-risk children* }\end{array}$ & $\begin{array}{l}\text { Indicated approaches for } \\
\text { children showing signs of } \\
\text { disorder* }\end{array}$ \\
\hline $\begin{array}{l}\text { create supportive } \\
\text { environments } \\
\text { support } \\
\text { safety } \\
\text { sense of belonging and } \\
\text { value } \\
\text { encourage positive } \\
\text { interaction with peers } \\
\text { and adults } \\
\text { structure } \\
\text { focus on strengths } \\
\text { foster positive learning } \\
\text { gently extend comfort } \\
\text { zone } \\
\text { reinforcement of 'brave' } \\
\text { behaviour } \\
\text { awareness and } \\
\text { monitoring of risk } \\
\text { factors } \\
\text { manage school } \\
\text { transition }\end{array}$ & $\begin{array}{l}\text { awareness of programs } \\
\text { for parents: } \\
\text { education about risk } \\
\text { parenting classes } \\
\text { support services } \\
\text { (including home visits) } \\
\text { for children: } \\
\text { assistance to overcome } \\
\text { difficulties } \\
\text { behaviour management } \\
\text { as per universal } \\
\text { approaches } \\
\text { awareness and } \\
\text { monitoring of risk } \\
\text { factors } \\
\text { formal and informal } \\
\text { communication with } \\
\text { parents }\end{array}$ & $\begin{array}{l}\text { referral } \\
\text { - available programs } \\
\text { - specialist services } \\
\text { - links with community } \\
\text { services }\end{array}$ \\
\hline
\end{tabular}




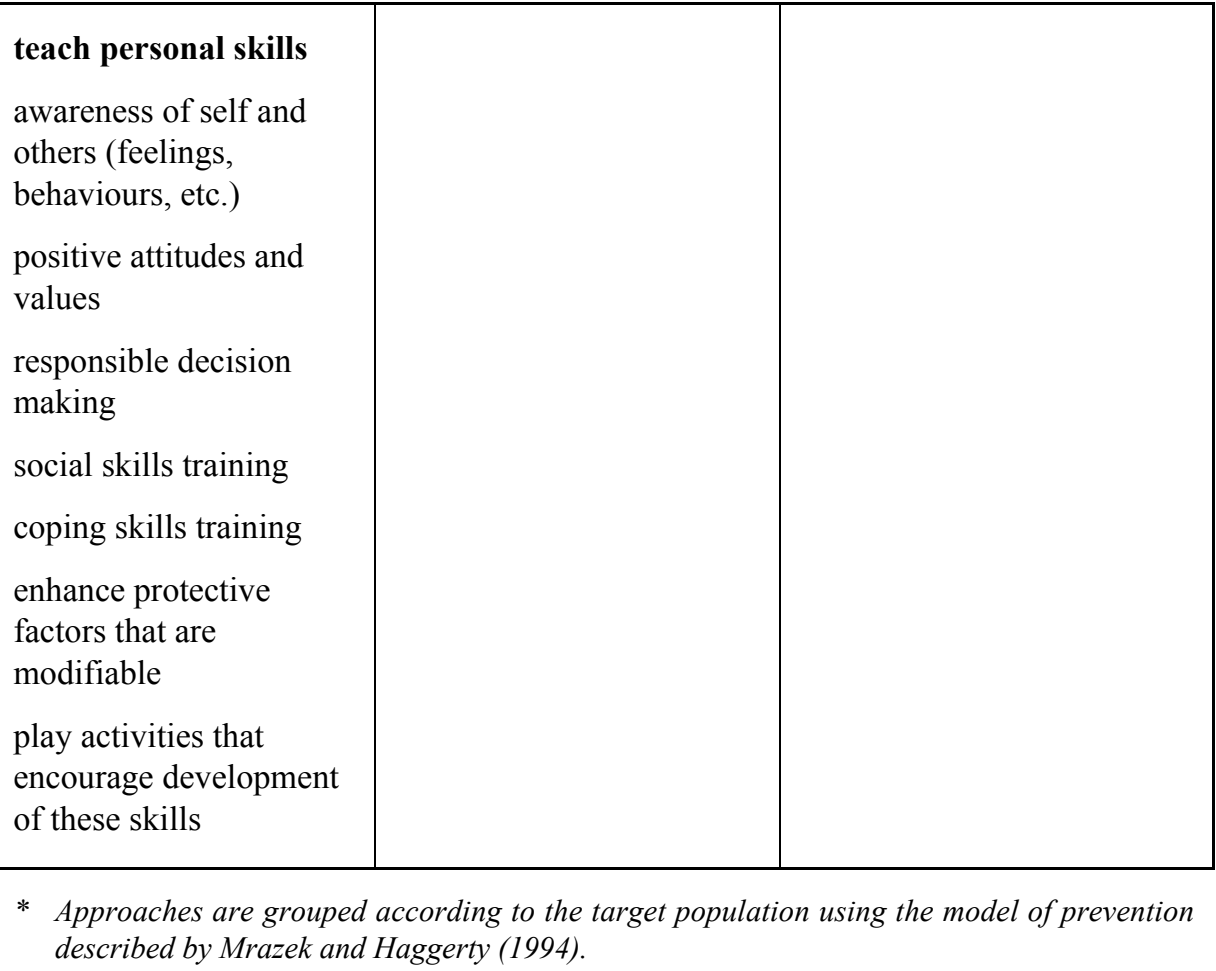

\section{Create caring, supportive environments}

In general, the quality of the environment in which a child develops will influence their health and wellbeing in later life (Moore, Ochiltree, \& Cann, 2002a). Supportive, safe environments that provide a sense of belonging and value, along with social justice, equity and respect, will be those that also promote mental health and prevent mental illness $(\mathrm{OMH}, 2002)$. The most influential environment for the young child is the home. However, educational settings, by virtue of the amount of time children spend at these institutions, have enormous potential to enhance resilience and promote positive mental health and wellbeing (Brooks, 2006). Indeed, the structured, predictable, supportive learning environment of school is protective in itself (Lynch, Geller, \& Schmidt, 2004). Further, for children already showing signs of risk or disorder and who are engaged in an external program designed to manage these issues, the school environment can play a key role in reinforcing and maintaining improvements made by the child (Currie, 2003).

Children's mental and social development can be profoundly affected by their environment (Farrell \& Travers, 2005). Importantly, when vulnerable children are engaged in a supportive environment that encourages interactions with peers, and protects them from the negative effects of stress and adversity, resilience is enhanced (Wolff, 1995). For example, social relationships at preschool and primary school have been associated with increased self esteem and improved psychological adjustment (Wolff, 1995). In a study of 9-12 year old children in South Australia, Howard and Johnson (2000) summarised the school-based environmental factors described by the respondents as increasing their resiliency. These factors included 
the provision of focused assistance to overcome learning difficulties and creating a safe and secure social and learning environment.

Experts are only beginning to operationalise the features of safe, supportive environments that can increase resilience, wellbeing and mental health. This means that very few practical strategies for creating such environments have been developed and evaluated. In a meta-analysis of 15 environment-centred programs for mental health promotion, Durlak and Wells identified the following key features associated with significant positive effects on school-aged children: improving the psychosocial aspects of the classroom environment (structure, interaction, social skills training), and modifying curricula to discuss positive mental health messages. The challenge for educators of young children is to communicate these messages using developmentally appropriate strategies (e.g., through the use of play, symbolism, and story telling, rather than written curriculum). Transitional programs that targeted first-time mothers and children of divorced parents and concentrated on assisting children to understand and cope with the transition from preschool to primary school also produced positive outcomes among children in this metaanalysis (Durlak \& Wells, 1997).

In addition, an environment that features limit setting and consistency and that creates partnerships with the family and community will provide an important basis for the development of resilient young people (Alvord \& Grados, 2005; Brooks, 2006; McGrath, 2000). Both formal and informal communication with parents is vital for ensuring a supportive, consistent and caring environment for young children, particularly when educators explain what is being worked on at school, why it is important, and give tips on how to foster resilience (Alvord \& Grados, 2005).

A general focus on the child's strengths, rather than weaknesses or deficits, will likely create an environment that fosters positive learning and support, and contribute to the development of resilience and wellbeing later in life, and encourage attachment to the teacher (Benard, 1993; Bendtro \& Larson, 2004; DEST, 2003; Koller \& Scvoboda, 2002). Elias (2003) suggested that the following practical strategies will assist educators create caring learning environments: greeting each student by name, encouraging students to reflect on what they have learned during the day, creating classroom rules that reinforce positive behaviours, and showing interest in the personal lives of children. Denham and Weissberg (2004) further suggested that, among preschoolers, the use of 'floor time' is a useful strategy to create positive attachment relationships and a caring learning environment. Here, the educator observes and then engages in play activities led by the child, and gently expands on the play using gestures and words that encourage the child to collaborate (Denham \& Weissberg, 2004).

Indeed, Guetzloe (2003) suggested that for educators of young children, one of the most important contributions is to provide a positive and supportive environment, satisfy their basic needs, and foster caring relationships with adults. While the importance of this approach at preschool and infants levels has been highlighted, a review of programs specifically implementing this strategy with 
younger age groups failed to locate any options (Greenberg et al., 2003). Further, Lynch, Geller and Schmidt (2004) highlighted the deficit in evidence-based, developmentally appropriate prevention programs for preschool children, despite the increased recognition of the potential for intervening during this period to increase resiliency.

\section{Teach personal skills to children}

Children with the fewest personal assets are most likely to be challenged during their development (Holmes, Slaughter, \& Kashani, 2001; Wolff, 1995). Educators can increase the personal effectiveness of children, provided they are adequately trained and supported to do so (Donovan \& Spence, 2000). Payton et al. (2000) outlined the key social and emotional learning competencies thought to best enhance outcomes for young people: awareness of self and others, positive attitudes and values, responsible decision making, social interaction skills.

At the school level, encouragement from teachers, involvement in extracurricular activities (art, sport, music, drama), and encouragement to develop at least one skill or ability that can be a source of pride or achievement for the young child (e.g., involvement in daily activities, assisting others, acting as a school patrol) will protect against the negative effects of adversity and stress in the young child's life (Alvord \& Grados, 2005; Doll \& Lyon, 1998; Donovan \& Spence, 2000).

During the school day, Perry (2002) suggested, it is important to offer activities that gently encourage children to extend their comfort zone, that teachers share stories of heroism and survival, help each child gain a sense of their own strengths and talents, encourage children to think of things they are no longer afraid of (e.g., swimming), and give children an opportunity to speak in front of a group. These activities are thought to reinforce 'brave' behaviours, and provide information about feared situations to increase a child's perception of control (Donovan \& Spence, 2000).

When teaching young children, an awareness of developmentally appropriate learning strategies is vital. For example, in contrast to older children, preschool children learn mainly through play and interaction, using one-on-one, creative approaches rather than through structured curriculum (BLS, 2006). A teaching style that encourages the development of personal skills will be the most effective, for example, storytelling, rhyming and acting games, having the children work together to build something, and creative activities such as art, dance, and music (BLS, 2006).

Educators can also model problem solving behaviour by talking over a problem and finding out what can be done about it, encouraging children to express their feelings (both positive and negative) and making opportunities for children to take on meaningful responsibilities or activities (Alvord \& Grados, 2005). Further, educators can encourage the development of coping strategies such as relaxation, slow breathing, etc., and teach them how to gain access to social support (Donovan $\&$ Spence, 2000). A meta-analysis of 14 early childhood programs revealed that education focused on improving the child's awareness and expression of feelings 
and causes of behaviours, along with training in problem solving skills, was most successful for children aged 2-7 years (Durlak \& Wells, 1997). Both of these domains need to be addressed, as problem solving alone did not result in improved resilience or mental health outcomes, or an increase in personal skills.

Elias (2003) suggests that everyday life skills could be taught to students by using experiential strategies. Strategies would include asking students to describe how they calm themselves down when distressed, encouraging and modelling the use of self-calming strategies, and providing children with opportunities to contribute to positive functioning of the classroom. In addition, Denham and Weissberg (2004) suggested that educators teach preschool children about emotions and behaviours by clarifying and explaining interactions with other children (e.g., why another child became upset), and linking a child's behaviour with a consequence (e.g., feeling, behaviour of another child). This approach may also lead to the development of empathy for others and a sense of self-control (Denham \& Weissberg, 2004). Children should also be encouraged to express emotions, guided by adults (e.g., parents and educators) who can discuss the reasons behind the child's feelings and link their thoughts with emotions and behaviours (Denham \& Weissberg, 2004). This approach is useful with young children who may not yet have the language skills to explain their emotional experiences.

\section{Participate in formal programs}

The majority of programs aimed at increasing resilience and preventing mental health problems among young children have focused on parents, and have generally provided education and/or support services to at-risk groups (OMH, 2002). In Australia, programs have included home visit programs (e.g., 'Best Beginnings', 'Parent Link home visiting services') designed to educate and support at-risk parents of young children; and parenting programs (e.g., 'Early Education', 'Positive Parenting Program') which teach parents how to manage problem behaviours and enhance positive behaviours (OMH, 2002). The key concepts to emerge from these programs are a focus on rewards rather than punishments, using alternatives to physical punishment and paying attention to good as well as bad behaviours (MyersWalls, 2004). Clear standards need to be set and maintained, and expressions of love and affection for the child and a commitment to explaining things to them are also important (Myers-Walls, 2004).

Preschool-aged children are receptive and amenable to messages from their educational setting (Lynch, Geller, \& Schmidt, 2004; Pianta \& Walsh, 1998). Some formal programs have been developed that enhance social competence and cognitive development in educational settings. These include teacher-oriented components designed to increase skills in effective behaviour management and creating supportive environments (Farrell \& Travers, 2005). The majority have been intended for older children and adolescents, with few formal, well-evaluated programs available for the preschool population (Lynch, Geller, \& Schmidt, 2004). This is an important gap that needs to be addressed, particularly within the Australian educational setting. 
Some programs for younger children, designed to be implemented by educators, are beginning to emerge. However, for the most part, these have yet to be applied and evaluated formally, and questions remain about the sustainability of these programs. For example, 'Zippy's Friends' is a school-based program for children aged 5-8 years. It is designed to prevent emotional problems. Although the details of the program are not yet published, evaluation results indicate that participation in the program was associated with improved social and coping skills compared to control schools. This was still apparent at the 12 month follow-up assessment (Ystgaard \& Mishara, 2006).

In addition, the 'Al's Pals: Kids Making Health Choices' program in Virginia, USA, covered children of low socioeconomic status aged 3-8 years who were classified as 'at-risk' (Lynch, Geller, \& Schmidt, 2004). In this program, teacher training, curriculum, and parental education were used to promote social and emotional competence, and were associated with an improvement in student resilience, increased social-emotional competence, and improved coping skills (Lynch, Geller, \& Schmidt, 2004). It is important to note, however, that the program was only designed to be delivered by experienced teachers; first-year teachers were excluded from participating. The Interpersonal Cognitive Problem Solving program additionally focused on teaching children aged 4-5 years a range of problem solving, communication and decision-making skills (Lynch, Geller, \& Schmidt, 2004).

In Australia, the Healthy Start Program (Farrell \& Travers, 2005) was developed to promote mental health among children in childcare settings. This program targeted the personal skills of childcare workers, and provided instruction on how to create supportive childcare environments. An evaluation of the program in Western Australia revealed that it was associated with increased educator confidence when discussing mental health issues with parents, an increase in the mental health literacy of workers, and an increase in knowledge of local services and programs for children and families (Farrell \& Travers, 2005).

The United States-based Head Start project targeted at-risk preschool children of socioeconomically disadvantaged backgrounds and aimed to increase their social and interaction skills (DoHHS, 2000). Children received an 8-week program that included school- and home-based interventions by community support people, and that emphasised social, health, and education services (DoHHS, 2000). Initial evaluations indicated positive effects of the program on school performance, peer relationships, school attendance and positive behaviours (Spernak et al., 2006).

The High/Scope Perry Preschool Program is one of the only preschool-based interventions that has been developed, implemented and researched in a randomised controlled trial, with outcomes mapped over a 35-year period. Teaching staff selected at-risk families of low socioeconomic status for participation in the program. Schools were randomly assigned to the Perry Preschool Program or a control group, and teachers delivered the program over an 8-month period using a combination of classroom lessons and weekly home visits. In particular, play activities were used to encourage problem solving, decision-making and social 
interaction. Significant improvements in level of schooling completed, employment rates and salary levels at age 40 were evident among those who received the program, versus those who did not. The intervention group also reported significantly less involvement in crime and use of social services (Schweinhart \& Weikart, 1998).

As previously discussed, this part of our review considered programs available in preschool years, rather than primary school. This was intended to avoid duplication with complementary work that was concurrently being undertaken by another group. The Australian Psychological Society has recently completed a comprehensive review of programs to promote mental health and resilience among primary school-aged children, as part of the KidsMatter initiative. At the time of writing this review, this report was not available.

While the results of some programs are often encouraging and informative, the sustainable impact of formal programs may be limited, given that they are often implemented as one-off, short-term initiatives, with little co-ordination with other competing programs and priorities, and little ongoing support or training of staff (Greenberg et al., 2003). Some of the projects described above (e.g., High/Scope Perry Preschool Program and Head Start) involved significant resources, infrastructure funding and specialist input. This raises questions about the feasibility of these programs on a broader scale and within the Australian setting.

\section{Refer children and families to specialist services}

Very few preschoolers who meet criteria for a psychiatric disorder are referred for a mental health evaluation or receive treatment. Prevention or early intervention of mental health problems and related risk factors among this group has not been a focus of research or activity (Alvord \& Grados, 2005; Burns et al., 1995; Donovan $\&$ Spence, 2000). This is a concern, given the results of recent pilot work in South Australia that indicates that among a sample of preschool children, 39\% were considered 'vulnerable' by their teachers, with few mental health resilience factors available to them (see DECS, 2006).

As indicated above, an awareness of the risk factors or early signs of difficulties among young children is fundamental to initiating prevention and early intervention strategies (DoHA, 2000). Some risk factors are not modifiable by educators, such as the family functioning and parental illness variables outlined in Table 1. However, others such as those in the school environment and in the young child may be amenable to change with appropriate intervention (DoHA, 2000). In addition, positive behaviour management will be a central strategy for managing risk factors with the onus on educators to establish firm limits to a child's behaviour. Important strategies include focusing on the things children can do, rather than the things they cannot do, and paying attention to children when they are doing positive things, rather than just negative things (Denham \& Weissberg, 2004). Importantly, educators should seek to include, rather than exclude, at risk children, continuing to engage them in a positive, supportive learning environment at school and enhancing the protective factors associated with improved outcomes. 
There are no clear guidelines to inform decisions about when a young child's behaviour is an early sign of disorder, as opposed to being developmentally appropriate (DoHHS, 2000). This is because early childhood is characterised by frequent changes in behaviour, cognitive and reasoning ability, and social interaction. Indeed, many of the risk factors outlined above (such as aggression, difficulty in paying attention, fearfulness or shyness) are considered a normal part of development of the young child (DoHHS, 2000). It is when combinations of these factors co-occur, and are present more frequently than expected for a long period of time, that professional assistance is recommended (CMHS, 2003; DoHHS, 2000). This is particularly the case when it seems that the child's physical, mental and/or social functioning is being affected (CMHS, 2003).

A key role for educators is to form partnerships with local community services, particularly those in the health sector, that can provide specialist assistance to children. Early intervention services may also be accessed via education departments and through the non-government sector. By being aware of available referral options, educators can facilitate pathways into care and early intervention, potentially offsetting longer term problems (DoHA, 2000).

\section{How can educators be trained to promote mental health and wellbeing among children?}

Given the importance of social and emotional wellbeing and resilience for children engaging in learning, and for their broader development, these issues need to become part of everyday classroom and learning situations (Greenberg et al., 2003). Yet, in a USA survey of masters-level teachers, $91 \%$ did not feel their undergraduate training prepared them to handle work-related and classroom situations that did not involve their content speciality (Koller \& Scvoboda, 2002). Educators may benefit from exposure to these ideas and strategies during their pre-service training, integrated with information about their content areas, in order to adequately prepare them for roles in promoting resilience and identifying children in need of support. The results of the High/Scope Perry Preschool Program highlighted the importance of specialised training of early childcare staff and educators of children that included early childhood development, child psychology and specialised early childhood education issues (Schweinhart \& Weikart, 1998). Educators in these roles should understand differences in relating style (e.g., nurturing and nondirective) and expectations for children aged five years or less, as they are different from those for older children (DfEE, 2001).

Indeed, Han and Weiss (2005) indicate that while much research attention has been given to the development of programs designed to enhance the mental health of students, there has been very little research looking at how teacher-training processes influence the implementation of these programs. This is a key issue likely to influence the success and sustainability of these approaches in practice (Moore, Ochiltree, \& Cann, 2002b). Although a range of institution-based factors will also influence the uptake of any mental health program within the early childhood setting, teacher self-efficacy, training and interest in these issues will also affect their internal motivation and openness to taking on these programs (Han \& Weiss, 
2005; Moore, Ochiltree, \& Cann, 2002a). These factors can be addressed at the preservice level, where their importance can be introduced to pre-service educators, along with guidance on how to maximise mental health and learning outcomes in their students. It is likely that such an approach will increase the potential for these ideas to be integrated into everyday practice, and educators may also be more receptive to participating in relevant school-based programs when they have graduated (Han \& Weiss, 2005; Rowe, 2003).

Further to this, Askell-Williams, Murray-Harvey, and Lawson (2005) suggested that an education student's mental model of teaching and learning is influenced by the way they were taught, with many people adopting similar teaching styles to the ones they have experienced. The way in which material is presented at the pre-service level could therefore influence the ways in which graduates structure their own teaching environments following graduation.

Problem-based learning (PBL) is a teaching approach that is becoming more popular in tertiary education. The model has been used extensively in medical training and is now being incorporated into pedagogical practices in other disciplines, including teacher education (Askell-Williams, Murray-Harvey, \& Lawson, 2005). The pedagogy of PBL may assist education students to challenge existing mental models of learning, and provides an opportunity to change and further develop their own methods of teaching. For example, following completion of a course with PBL cases, students displayed improved critical thinking, knowledge building, understanding of theory-practice relationships and professional collaboration, all of which are evidence of a positive change in mental models of classroom teaching and learning. The use of PBL pedagogical approaches at the preservice level may be a way for pre-service teachers to internalise and practise these approaches following graduation.

In early childhood settings in Australia, children are educated and cared for either by qualified teachers (holding a university degree) or by support staff who may hold a Children's Services qualification - through institutes of technical and further education (TAFE) or another registered training organisation (RTO) - or who may have no formal qualification. In primary school, students are taught by qualified teachers whose pre-service training was in a university setting, complemented by a designated period of practical experience in schools.

Australian Children's Services qualifications are governed by a national training package known as $\mathrm{CHC} 02$, which includes a number of competencies that cover aspects of children's wellbeing. This training package is currently under review. Learners in Children's Services courses may have had access to the CommunityMindEd resource during their training. CommunityMindEd is a mental health promotion and suicide prevention resource for vocational education teachers that is linked to a range of community services qualifications, although it is not specifically linked to many of the Children's Services competencies. CommunityMindEd was produced in 2005 and is entering a new phase in which there is a renewed focus on active dissemination, which may increase its use in the TAFE/RTO sector. 
University based training of educators is more complex and diverse. Many universities across Australia offer education qualifications that allow for specialisation in early childhood or primary education. In the last few years, several state and territory governments have established or reviewed their teaching regulatory authorities, now variously known as registration boards, colleges or institutes. Most have similar roles, including developing or reviewing professional standards for teachers and making recommendations on the accreditation of preservice teacher education programs.

At the time of writing this review, there was no national curriculum for teacher education in Australia and no nationally-agreed set of competencies or professional standards. In 2003 the Ministerial Council on Employment, Education, Training and Youth Affairs (MCEETYA) endorsed a National Framework for Professional Standards for Teaching and in 2005 the Council moved that all jurisdictions should align their standards with this framework. Teaching Australia (www.teachingaustralia.edu.au) was launched in December 2005 and is an organisation established by the federal Department of Education, Science and Training. It has its own constitution and seeks to support and advance the effectiveness and standing of the teaching profession. This organisation is working towards a national system for accrediting teacher education programs and a national framework for teaching standards. However it is unclear at this stage how such frameworks or systems will interface with state and territory standards.

There are now professional or draft standards in all but one of Australia's states and territories, but none of these differentiate between early childhood, primary and secondary teachers. In an internet search conducted between July and October 2006, no evidence was found of any standards specifically for children's or young people's mental health. However several jurisdictions do refer broadly to the need for educators to promote trusting and respectful relationships with learners, to foster students' wellbeing and to create supportive learning environments.

Professional standards, where available, are used to guide the registration of practitioners and as a point of reference in accrediting teacher education programs. However, they are sufficiently broad to allow considerable freedom of interpretation for teachers' preparation. In practice, considerable diversity is likely to remain in teacher education programs, and will in part be determined by subject coordinators' professional interests, research areas and educational philosophies.

There are 106 campuses across Australia that offer a relevant program, distributed across all states and territories. From August to November 2006, the Hunter Institute of Mental Health consulted 103 teacher educators in early childhood and primary programs, covering the majority of these institutions. This consultation took the form of semi-structured face-to-face interviews with program convenors and other stakeholders at university campuses in all states and territories.

The consultation showed that teacher educators perceive children's mental health and wellbeing to be important for teachers, but that programs vary considerably in their coverage of issues. Many respondents felt that there would be 
benefits in addressing mental health topics more formally and in greater depth, with a focus on promoting wellbeing and identifying students at risk. The major barriers to sustainable integration were cited as pressure on program content, reduction of student contact time, pressures on lecturers and tutors, staff turnover and staff casualisation. There was support from the majority of respondents for the provision of high-quality Australian teacher education resources to support this aim. Most favoured a multimedia format utilising a problem based learning approach.

The Australian Government has previously supported the development and dissemination of a similar multimedia teacher education resource for the preparation of secondary school teachers (www.responseability.org). Evaluation of this initiative, which has been operating continuously since 2000, has shown some evidence of success in enhancing the inclusion of mental health in teacher education. Evaluation strategies have included the analysis of qualitative and quantitative data from teacher educators and tertiary students on the use of resources and the shortterm impacts of exposure, as well as a small pilot study examining the views of graduates after one year of practice.

Educators with university qualifications also have the option of pursuing postgraduate studies in children's mental health and wellbeing. Australian universities currently provide a number of graduate certificates, postgraduate diplomas and masters degrees in child and adolescent mental health or school counselling. These are offered by faculties of education, psychology, welfare, social work, nursing and other health-related disciplines. The extent to which such programs are utilised by teaching graduates was beyond the scope of this review.

Finally, a range of professional development opportunities and programs are available to teachers already working in the educational setting, focusing on enhancing the mental health and wellbeing of their students. These include workshops and training programs, online resources and courses, and practice-based textbooks from education-focused publishing companies. However, the extent to which these opportunities and resources are accessed and used to enhance teaching practices is unknown. The use of such resources will depend in part upon a practitioner's interest in mental health issues and the perceived value of these programs or approaches.

Notwithstanding the importance of supporting educators to enhance the mental health and wellbeing of children in their care, there is a very real need to assist educators to address mental health needs among their colleagues and within themselves, given the high rates of stress and burnout in the teaching profession (Koller \& Scvoboda, 2002). Crouter and Bumpus (2001) suggested that feelings of overload and stress can often translate into higher levels of conflict and poorer adult-child relations, which are in turn associated with poor adjustment of the child. High staff turnover will also negatively affect the development of a young child, as a key benefit of early childcare is the development of secure attachments with safe, supportive adults over several years (DfEE, 2001). Better preparing pre-service teachers for the demands associated with early childhood and primary school 
settings-including mental health and wellbeing - could improve their transition into teaching and their retention in the profession.

\section{References}

Aguirregabiria A, 2006, Positive mental health promotion from birth to ten years. Paper presented at the Promotion of Mental Health and Prevention of Mental and Behavioral Disorders: Developing Resilience and Strength Across the Lifespan, Oslo, Norway.

Alvord MK \& Grados JJ, 2005, Enhancing resilience in children: A proactive approach. Professional Psychology: Research and Practice, 36(3), 238-245.

APA, 2000, Diagnostic and Statistical Manual of the Mental Disorders, Fourth Edition, Text Revision. American Psychiatric Association, Washington.

Askell-Williams H, Murray-Harvey R \& Lawson M, 2005, Extending teacher education students' mental models of teaching and learning through Problem Based Learning. Paper presented at the Annual Conference of the Australian Association for Research in Education, Parramatta, Sydney.

Beitchman JH, Inglis A \& Schachter D, 1992a, Child psychiatry and early intervention II: The internalising disorders. Canadian Journal of Psychiatry, 37(May), 234-239.

Beitchman JH, Inglis A \& Schachter D, 1992b, Child psychiatry and early intervention IV: The externalising disorders. Canadian Journal of Psychiatry, 37(May), 245-249.

Benard B, 1993, Fostering resiliency in kids. Educational Leadership, 51(3), 44-48.

Bendtro L \& Larson S, 2004, The resilience code: Finding greatness in youth. Reclaiming Children and Youth, 12(4), 194-200.

Bernstein G, Borchardt CM \& Perwien AR, 1996, Anxiety disorders in children and adolescents: A review of the past 10 years. Journal of the American Academy of Child and Adolescent Psychiatry, 35(9), 1110-1119.

BLS, 2006, Teachers: Preschool, Kindergarten, Elementary, Middle, and Secondary, from www.bls.gov/oco/ocos069.htm

Brooks JE, 2006, Strengthening resilience in children and youths: Maximising opportunities through the schools. Children \& Schools, 28(2), 69-76.

Burns BJ, Costello JE, Angold A, Tweed D, Stangl D, Farmer E, et al., 1995, Children and young people's mental health service use across service sectors. Health Affairs, 14(3), 147-159. 
Burns JM, Andrews G \& Szabo M, 2002, Depression in young people: what causes it and can we prevent it? Medical Journal of Australia, 177(October), S93-S95.

CMHS, 2003, When Teachers Should Refer Students to a Mental Health Professional, from mentalhealth.samhsa.gov/publications/allpubs/ KEN01-0113/default.asp

Crouter AC \& Bumpus MF, 2001, Linking parents' work stress to children's and adolescents' psychological adjustment. Current Directions in Psychological Science, 10(5), 156-159.

Currie J, 2003, What we can expect from early childhood intervention programs. Social Policy Report, 17(1), 5.

DECS, 2006, Healthy Minds/Healthy Futures: Child Mental Health and Wellbeing Study. Predicting and Improving Mental Health Resilience in Early Childhood. Summary of Research Findings From 2005 for Educators. www.decs.sa.gov.au/speced2/files/pages/chess/hsp/Research/final_2 005_parent_results.pdf

Denham SA \& Weissberg RP, 2004, Social-emotional learning in early childhood: What we know and where to go from here. In: E. Chesebrough, P. King, T. P. Gullotta \& M. Bloom (eds) A Blueprint for the Promotion of Prosocial Behaviour in Eary Childhood. Kluwer Academic/Plenum Publishers, New York, USA.

DEST, 2003, REDI for the Classroom: A resilience approach to drug education. Commonwealth Department of Education, Science and Training, Canberra.

DfEE, 2001, Promotion Children's Mental Health Within Early Years and School Settings (Reference: 0112/2001). Department for Education and Employment, Nottingham, UK.

DoHA, 2000, Promotion, Prevention and Early Intervention for Mental Health: A Monograph. Mental Health and Special Programs Branch, Commonwealth Department of Health and Aged Care, Canberra Australia.

DoHHS, 2000, Mental Health: Report of the Surgeon General: Department of Health and Human Services, Substance Abuse and Mental Health Services Administration, Center for Mental Health Services, National Institute of Mental Health.

Doll B \& Lyon MA, 1998, Risk and resilience: Implications for the delivery of educational and mental health services in schools. School Psychology Review, 27(3), 348-363. 
Donovan CL \& Spence SH, 2000, Prevention of childhood anxiety disorders. Clinical Psychology Review, 20(4), 509-531.

Durlak J \& Wells A, 1997, Primary prevention mental health programs for children and young people: a meta-analytic review. American Journal of Community Psychology, 25(2), 115-152.

Egger HL \& Angold A, 2006, Common emotional and behavioral disorders in preschool children: presentation, nosology, and epidemiology. Journal of Child Psychology and Psychiatry, 47(3-4), 313-337.

Elias MJ, 2003, Academic and social-emotional learning. In: I. B. O. Education (ed) Educational Practices Series II: International Academy of Education (www.ibe.unesco.org).

Farrell P \& Travers T, 2005, A healthy start: Mental health promotion in early childhood settings. Australian E-journal for the Advancement of Mental Health, 4(2), 1-10.

Friedman R \& Chase-Lansdale P, 2002, Chronic Adversities. In: M. Rutter \& E. Taylor (eds) Child and Adolescent Psychiatry: Modern Approaches, 4th Edition. Blackwell Publishing, Oxford.

Greenberg MT, Weissberg RP, O'Brien MU, Zins JE, Fredericks L, Resnik H, et al., 2003, Enhancing school-based prevention and youth development through coordinated social, emotional and academic learning. American Psychologist, $58(6-7), 466-474$.

Guetzloe E, 2003, Depression and disability in children and adolescents. ERIC Clearinghouse on Disabilities and Gifted Education, ED482340, 1-8.

Han SS \& Weiss B, 2005, Sustainability of teacher implementation of school-based mental health programs. Journal of Abnormal Child Psychology, 33(6), $665-679$.

Holmes SE, Slaughter JR \& Kashani J, 2001, Risk factors in childhood that lead to the development of conduct disorder and antisocial personality disorder. Child Psychiatry and Human Development, 31(3), 183-193.

Howard S \& Johnson B, 2000, What makes the difference? Children and teachers talk about resilient outcomes for children 'at-risk'. Educational Studies, 26(3), 321-337.

Koller JR \& Scvoboda SK, 2002, The application of a strengths-based mental health approach in schools. Childhood Education, 78(5), 291-294.

Lagges AM \& Dunn DW, 2003, Depression in children and adolescents. Neurologic Clinics of North America, 21, 953-960. 
Luther S, Cicchetti D \& Becker B, 2000, The construct of resilience. Child Development, 71, 543-562.

Lynch KB, Geller SR \& Schmidt MG 2004, Multi-year evaluation of the effectiveness of a resilience-based prevention program for young children. The Journal of Primary Prevention, 24(3), 335-353.

McGrath H, 2000, The BOUNCE BACK! Resiliency Program: A pilot study. Paper presented at the Annual Conference of the American Educational Research Association, New Orleans, USA.

Moore T, Ochiltree G \& Cann W, 2002a, BEST START Effective Intervention Programs: Examples of Effective Interventions, Programs and Service Models. Melbourne, Victoria: Department of Human Services (Community Care Division), VicHealth. Available at: www.dhs.vic.gov.au/comcare

Moore T, Ochiltree G \& Cann W, 2002b, BEST START Evidence Base Project: The Evidence Base Underlying Investment in the Early Years (children 0-8 years). Melbourne, Victoria: Department of Human Services (Community Care Division), VicHealth. Available at www.dhs.vic.gov.au/commcare

Mrazek PJ \& Haggerty RJ, 1994, Reducing the Risks for Mental Disorders: Frontiers for Preventive Intervention Research. National Academy Press, Washington, USA.

Myers-Walls JA, 2004, Positive parenting: Key concepts and resources. Journal of Family and Consumer Services, 96(4), 10-13.

OMH, 2002, Mental Health Promotion and Illness Prevention Policy. Office of Mental Health, Department of Health, Western Australia.

Payton JW, Wardlaw DM, Gracyzk PA, Bloodworth MR, Tompsett CJ \& Weissberg RP, 2000, Social and emotional learning: A framework for promoting mental health and reducing risk behaviour in children and youth. Journal of School Health, 70(5), 179-185.

Perry BD, 2002, Resilience: Where does it come from? Scholastic Early Childhood Today, 17(2), 24-25.

Pianta RC \& Walsh DJ, 1998, Applying the construct of resilience in schools: Cautions from a developmental systems perspective. School Psychology Review, 27, 407-417.

Rowe K, 2003, The importance of teacher quality as a key determinant of students' experiences and outcomes of schooling. Paper presented at the ACER Research Conference, Melbourne, Australia. 
Sawyer MG, Arney FM, Baghurst PA, Clark JJ, Graetz BW, Kosky RJ, et al., 2001, The mental health of young people in Australia: Key findings from the Child and Adolescent Component of the National Survey of Mental Health and Well-Being. Australian and New Zealand Journal of Psychiatry, 35(6), 806-814.

Schweinhart LJ \& Weikart DB, 1998, The High/Scope Perry Preschool Program. In: R. H. Price, E. L. Cowen, R. P. Lorion \& J. Ramso-McKay (eds) Fourteen Ounces of Prevention: A Casebook for Practitioners. American Psychiatric Association, Washington, USA.

Spernak SM, Schottenbauer MA, Ramey SL \& Ramey CT, 2006, Child health and academic achievement among former head start children. Children and Youth Services Review, 28(10), 1251-1261.

Werner EE, 1995, Resilience in development. Current Directions in Psychological Science, 4, 81-85.

Wolff S, 1995, The concept of resilience. Australian and New Zealand Journal of Psychiatry, 29, 565-574.

Ystgaard M \& Mishara B, 2006, Children and coping: Evaluation of the schoolbased program Zippy's friends. Paper presented at the Promotion of Mental Health and Prevention of Mental and Behavioral Disorders: Developing Resilience and Strength Across the Lifespan, Oslo, Norway. 